\title{
MMP8 wt Allele
}

National Cancer Institute

\section{Source}

National Cancer Institute. MMP8 wt Allele. NCI Thesaurus. Code C49734.

Human MMP8 wild-type allele is located in the vicinity of $11 \mathrm{q} 22.3$ and is approximately 12 $\mathrm{kb}$ in length. This allele, which encodes neutrophil collagenase protein, is involved in the regulation of matrix remodeling via the degradation of fibrillar collagens (types I, II and III). 